ARTICLE

\title{
Admiration for Islamist groups encourages self-sacrifice through identity fusion
}

\author{
Á. Gómez ${ }^{1,2,5}$, J. J. Bélanger ${ }^{3,5 凶}$, J. Chinchilla ${ }^{2}$, A. Vázquez ${ }^{1,2}$, B. M. Schumpe ${ }^{3}$, C. F. Nisa(i) ${ }^{3}$ \& S. Chiclana ${ }^{4}$
}

The psychological mechanisms that lead terrorists to make costly sacrifices for their ideological convictions are of great theoretical and practical importance. We investigate two key components of this process: (1) the feeling of admiration toward ingroup members making costly self-sacrifices for their ideological group, and (2) identity fusion with religion. Data collected in 27 Spanish prisons reveal that jihadists' admiration toward members of radical Islamist groups amplifies their willingness to engage in costly sacrifices for religion in prison. This effect is produced because admiration toward radical Islamist groups has a binding effect, increasing identity fusion with religion. Five additional experiments provide causal and behavioural evidence for this model. By showing that admiration for ingroup members increases identity fusion, which in turn makes individuals prone to engage in costly pro-group behaviours, we provide insights into the emotional machineries of radicalization and open new avenues for prevention strategies to strengthen public safety.

\footnotetext{
${ }^{1}$ Artis International, Washington, DC, USA. ${ }^{2}$ Universidad Nacional de Educación a Distancia, Madrid, Spain. ${ }^{3}$ New York University Abu Dhabi, Abu Dhabi, United Arab Emirates. ${ }^{4}$ Secretaría General de Instituciones Penitenciarias Ministerio del Interior, Madrid, Spain. ${ }^{5}$ These authors contributed equally: Á. Gómez, J.J. Bélanger. ${ }^{凶}$ email: jocelyn.belanger@nyu.edu
} 


\section{Introduction}

dmiration is a social emotion that is evoked by observing laudable behaviours-such as generosity, loyalty, fidelity, and commitment (Immordino-Yang et al., 2009; Pohling and Diesner, 2016; Schindler et al., 2013)-in others. In group dynamics, admiration can lead members who marvel at the conviction of their peers to become inspired to engage in similar, if not costlier, behaviours to support their group. For groups engaged in violence, this contagious effect can have dramatic consequences. Two contrasting examples illustrate this point. On March 15, 2019, a person previously unknown to authorities attacked two mosques in Christchurch, New Zealand, killing 51 people and injuring 49. Australian Prime Minister Scott Morrison described the perpetrator as an "extremist, right-wing, violent terrorist" with an admiration for groups supporting violence against Muslims.

Less than 3 years earlier, up to 30,000 foreign fighters from 100 countries joined the Islamic State (ISIS) following its proclamation of an Islamic caliphate forged through mass executions, genocide, and suicide bombings (UN, 2019). Among them, thousands of indoctrinated child soldiers ("cubs of the caliphate") are spurred into action through the lure of status, purpose, and admiration (Nyamutata, 2020).

But while these examples illustrate the range of political behaviours admiration can beget, they do not explain why admiration for an individual or a group produces greater willingness to engage in costly sacrifices. What is it about admiration that makes individuals willing to risk life and limb on the altar of an ideology? Answering this question and understanding the processes that drive active involvement in ideological groups has far-reaching social and geopolitical ramifications, and may help to inform policy decisions to prevent radicalization.

In the present research, we propose that identity fusion-an individual's visceral commitment to a group or ideology-is what binds admiration and self-sacrifice together. In particular, we suggest that admiration viscerally connects people to their group or their convictions, which in turn leaves them prone to making costly sacrifices for their deep-seated beliefs. To examine this emotion-driven response, we report on fieldwork conducted with jihadists (ISIS and al-Qaeda supporters) incarcerated in Spain, with a control group of Muslims imprisoned for crimes unrelated to terrorism (Study 1) and combine this field study with five online experimental studies offering causal relation and refinement to our model tested in prisons.

\section{Literature review}

According to contemporary emotion theories, admiration is an other-focused emotion (Algoe and Haidt, 2009; Onu et al., 2016) that hinges on having "regard for someone or something considered praiseworthy or excellent" (Oxford English Dictionary, 2020). Admiration is often described as a transfiguring experience bestowing a kind of enlightenment leading to important personal changes (Pohling and Diessner, 2016). It is important to highlight that admiration is conceptually different from other social emotions that are positively valenced such as gratitude, awe and adoration, which are associated with different elicitors and action tendencies. Specifically, whereas admiration is evoked by witnessing manifestations of virtue or excellence, gratitude occurs when someone is beneficiary of another's moral excellence (Onu et al., 2016). Awe also originates from witnessing virtue or excellence, but the event is perceived as so extraordinary and overwhelming that it is beyond one's comprehension (Keltner and Haidt, 2003). Furthermore, whereas admiration motivates emulation and self-improvement, gratitude motivates paying back the benefactor and awe induces a state of contemplation and submission (Onu et al., 2016). And while admiration motivates the internalization and emulation of ideals embodied by an outstanding role model, "adoration stimulates adherence to the teachings and expectations of a meaning maker and benefactor perceived as superhuman or sacred" (Schindler et al., 2013).

Although relatively little empirical work has been conducted on admiration, some scholars use the label moral elevation for admiration elicited by acts of virtue and restrict use of the term admiration to emotional responses to non-moral excellence (Algoe and Haidt, 2009; Haidt, 2003). While these two concepts differ in some respects, moral elevation and admiration are both associated with outcomes relevant to the present research including self-improvement, the creation of social bonds, and the emulation of ideals embodied by outstanding exemplars (Algoe and Haidt, 2009). Therefore, given that moral elevation and admiration energize people to approach successful others and learn from them (Henrich and Gil-White, 2001; Smith, 2000), we postulate that both should produce identity fusion. Moreover, to contribute to this incipient literature, we also test whether admiration evoked by moral virtue produces greater identity fusion than admiration evoked by personal skills.

Theoretical explanations of the evolutionary origins and functions of admiration are rooted in the gregarious nature of human beings and their need to belong (Baumeister and Leary, 1995). The social functional approach to the study of emotions, proposes that admiration toward ingroup members creates greater group cohesion and devotion to its members (Stellar et al., 2017). According to multilevel selection theory, admiration motivates individuals to transcend their narrow personal interests and to make sacrifices to help the group achieve its goals (Pohling and Diessner, 2016). In fact, there is evidence suggesting that individuals' readiness to self-sacrifice for a cause is positively related to admiring exemplars that engage in costly behaviours (Bélanger et al., 2014). A large body of evidence also indicates that admiration promotes prosocial behaviours (Schnall et al., 2010; Vyver and Abrams, 2015) and behaviours that increase the welfare of others (Penner et al., 2005) — such as charitable donations and volunteering (Cox, 2010; Schnall et al., 2010; Vianello et al., 2010; Vyver and Abrams, 2015). Likewise, there is a positive correlation between employees' admiration for their organizational leaders and self-reported feelings of altruism, commitment, courtesy, and compliance at work (Vianello et al., 2010). A specific example of this view shows a relationship between Hong Kong residents' feelings of admiration toward pro-democracy protesters persecuted by the Chinese government, and their willingness to take political actions to challenge the government's anti-democratic policies (Sweetman et al., 2013).

However, despite indications that admiration is associated with self-sacrifices for the sake of a group, the scientific literature has failed to show any evidence, experimental, or otherwise, explaining this relationship. We postulate that the core explanation of this phenomenon is identity fusion with the group.

Identity fusion is a visceral feeling of oneness with a group, marked by strong allegiance to each group member ("relational ties") and to the group as a whole including their goals and values ("collective ties"; Gómez et al., 2019; Swann et al., 2012). Together, these attachments trigger feelings of agency that motivate pro-group actions. For strongly fused individuals, the borders between personal identity (the part of our identity that derives from the characteristics that make us unique) and social identity (the part that stems from our membership in groups) become porous (Swann et al., 2012).

Furthermore, when fused individuals engage in pro-group behaviours, they experience a profound sense of personal agency that they put at the service of the group's wellbeing. Research has 
also shown that activating personal or social identities produces similar responses-namely, a greater willingness to fight and die for the group (Gómez et al., 2011a; Swann et al., 2009). Moreover, fused individuals are strongly attracted to other group members; they value them as if they were brothers and sisters. Once individuals are fused with a group, they tend to remain fused (Gómez et al., 2020; Swann et al., 2012).

Most recent theories on radicalization, such as the devoted actor model and the $3 \mathrm{~N}$ model of radicalization (Bélanger et al., 2018; 2019; Gómez et al., 2017; Kruglanski, Bélanger et al., 2019; Kruglanski, Webber et al., 2019; Sheikh et al., 2016; Vázquez et al., 2020), recognize identity fusion as an important psychological factor connecting individuals to radical networks, and in predicting one's willingness to engage in violence on the group's behalf. The devoted actor model proposes that individuals fused with a group with which they share a sacred value are particularly willing to display costly sacrifices for the group and the value (Gómez et al., 2019). The $3 \mathrm{~N}$ model of radicalization, on the other hand, posits that the need for personal significance (i.e., the desire to matter, to experience a meaningful existence) is related to a "collectivistic shift" orienting individuals toward joining and strongly identifying with a group, which may lead to violent extremism if the ideological narrative of the group elevates violence as a means of attaining significance (Bélanger et al., 2018; 2019; Kruglanski, Bélanger et al., 2019; Kruglanski, Webber et al., 2019). In this process, members of the group validate the narrative by respecting and venerating those who engage in the requisite violence against the enemies of the group.

Identity fusion has also been linked to behaviours such as the refusal to leave the group (Gómez et al., 2011b); denial of group wrong-doing (Besta et al., 2014); diminished quality of life after one's group is defeated (Buhrmester et al., 2012); the willingness to participate in extreme forms of protest on the group's behalf (Kunst et al., 2018); maximizing ingroup advantage over an outgroup, even at one's personal expense (Buhrmester et al., 2018); protecting group reputation (Ashokkumar et al., 2019); sacrificing personal relationships (Swann et al., 2015); relative intergroup formidability (Gómez et al., 2017); donating to charity (Buhrmester et al., 2014; Swann et al., 2010); writing supportive notes to victims of terrorist attacks (Buhrmester et al., 2014); behaving aggressively toward outgroup members in videogames (Vázquez et al., 2020); and the desire to retaliate against outgroup members (Fredman et al., 2017). Recently, research has found that identity fusion also extends to other targets such as ideological convictions, other individuals, animals, objects, or even activities (Gómez et al., 2020).

Although the relationship between identity fusion and costly pro-social behaviours has been widely documented, research on the antecedents of identity fusion is scarcer.

Two main factors have been proposed as potential causes of identify fusion: (1) shared biology and (2) shared experiences. There is ample evidence to support both approaches.

The first cause-shared biology-is backed by data showing that monozygotic twins are more fused with their sibling than dizygotic twins (Vázquez et al., 2017), and are also more willing to die for their sibling (Tornero et al., 2017). Several investigations have demonstrated that the family is the group for whom individuals are most willing to die-a robust finding shown in 11 countries across five continents (Swann et al., 2014), including an investigation with Libyan revolutionaries during the 2011 conflict in Libya (Whitehouse et al., 2014), a study conducted with frontline fighters against ISIS (Gómez et al., 2017), and a study conducted with young men in Mosul, Iraq (Atran, 2019). Experimental research has also shown that priming the existence of shared biological attributes between members of a group increases the perception of family-like ties, which, in turn, increases people's willingness to engage in costly sacrifices for the sake of the group (Swann et al., 2014).

The second possible cause-shared experiences-is also well documented. Several investigations have offered empirical evidence that sharing intense experiences with ingroup members fosters fusion with the group (Kapitány et al., 2018; Kavanagh et al., 2018; Misch et al., 2018), when such experiences are positive (Kavanagh et al., 2018), but particularly if these experiences are negative, traumatic, or dysphoric (Jong et al., 2015; Newson et al., 2016; Segal et al., 2018; Whitehouse et al., 2017). Similarly, participating in collective gatherings, like folkloric marches and religious celebrations, could increase fusion (Páez et al., 2015; Zumeta et al., 2016), while engaging in ritual practices or recalling episodic memories of pilgrims' routes contribute to maintaining identity fusion (Lobato and Sainz, 2019).

Beyond these findings, however, research has been silent on the role of social emotions in encouraging identity fusion. In the present research we extend and integrate previous work on emotions, identity fusion, and violent extremism by proposing that admiration increases costly sacrifices for an ideology through greater identity fusion.

To test the validity and real-world relevance of our model, we first report data from a quantitative field study conducted with imprisoned jihadists in Spain that compares their responses to a control group of criminals (also Muslims) imprisoned for crimes unrelated to terrorism. Following this unique field study, we present five experimental studies to ensure that our claims are causal and robust (see Table 1 for overview of studies and research questions addressed).

The study with prisoners and the online studies were approved by the Institutional Review Board of the authors' university and conducted with the permission of the prison's authority. All studies were conducted in accordance with the rules and regulations of the American Psychological Association. Informed consent was obtained from all participants before they took part in the studies. Participant anonymity was assured along with explicit assurance that interviews or experiments involving verbal answers to questionnaires could be terminated at will. Participants agreed on a voluntary basis to participate in interviews and experiments involving answers to questionnaires. In accordance with standard IRB protocols, they were reminded that they could abandon the investigation at any time if they felt uncomfortable. Participants were thanked and debriefed at the end of the interview and questionnaire. They received the contact information of the PI in case they were interested in receiving further information.

Study 1: Admiration toward radical Islamist groups increases identity fusion with religion and willingness to engage in costly sacrifices among imprisoned jihadists. We tested whether imprisoned jihadists (vs. non-terrorist criminals) would report greater admiration toward radical Islamist groups, which in turn would be associated with greater identity fusion with religion, and greater willingness to engage in costly sacrifices for religion in prison. The study was conducted in Spain. The Spanish Penal code (articles 571-580) defines terrorism as crimes carried out for any of the following purposes: (1) Subvert the constitutional order, or seriously suppress or destabilize the functioning of the political institutions or the economic or social structures of the State, or compel the public powers to carry out an act or to refrain from doing so, (2) seriously alter public peace, (3) seriously destabilize the cooperation of an international organization, and (4) provoke a state of terror in the population or in part of it. Terrorist acts include crimes against the Crown, life, physical or moral integrity, liberty, heritage, public health, and natural 


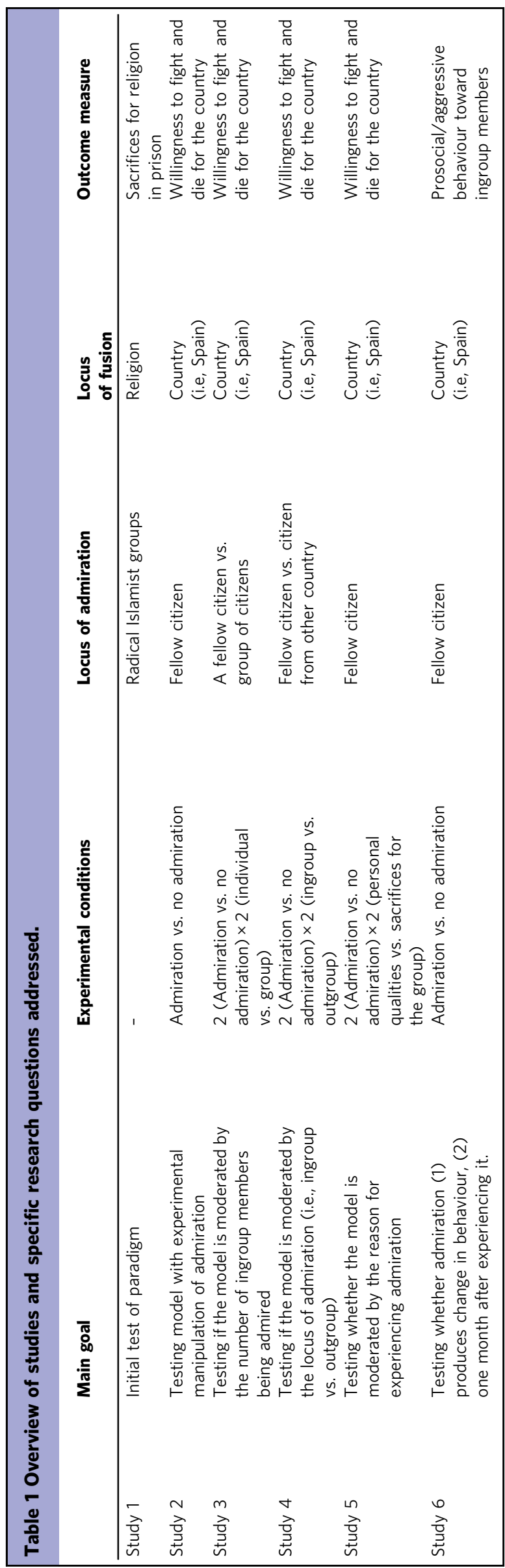

resources or the environment. Possession, traffic and deposit of weapons, ammunition or explosives, and the seizure of aircrafts, ships or other means of transport are also included under the umbrella of terrorism. Finally, computer intrusion and computer damage are typified as terrorism as well when they serve some of the above stated goals.

\section{Method}

Ethics compliance. All studies were approved by the Institutional Review Board of the authors' university and informed consent was obtained from participants. The current study was also approved by the prison's authority.

Participants. We selected two sub-samples of prisoners who participated in a broader research and that responded to the questions prepared for the goal of the present investigation. One of the subsamples included returning ISIS foreign fighters, participants in the 2004 and 2017 attacks in Madrid and Barcelona, respectively, and others convicted of plotting terrorist attacks for Islamist causes. The other subsample included Muslims involved mainly in petty criminal activities (drug trafficking, robbery, etc.). Prisoners in this research were all men and Muslims. Thirty-six jihadists $\left(M_{\text {age }}=32.81, \mathrm{SD}_{\text {age }}=8.80\right)$ and 35 non-terrorist criminals $\left(M_{\text {age }}=35.77, \mathrm{SD}_{\text {age }}=8.70\right)$ located in 27 Spanish prisons took part in the study.

Procedure. Approximately one week before the interviews, prisoners were asked if they would like to participate voluntarily in a research about life conditions in prison, their feelings and emotions related to different groups they belong to, and their values. The day of the interview, participants were individually interviewed by trained members of our research team in a private room within the prison complex which was habilitated for the purpose of the study by the prison staff.

At the beginning of the interview, participants were informed that all the responses would be anonymous, that they were free to not respond to any of the questions, and that no benefit or changes to their sentence or conditions would follow no matter if they chose to participate or decline to take part in this study. After taking part in a semi-structured interview and answering some questions unrelated to the purposes of the study, participants responded to a series of items measuring their admiration toward radical Islamist groups, their fusion with religion, and their willingness to engage in costly sacrifices for religion in prison. In all the following studies, responses to the measures of perceived cost of sacrifice and willingness to fight and die were scored on Likert-type scales ranging from 1 (totally disagree) to 7 (totally agree), whereas responses to the rest of the measures were scored on scales ranging from 0 (totally disagree) to 6 (totally agree).

Feelings of admiration were measured with a single item. We asked each participant to "indicate to what degree you admire the members of Islamist activist/radical groups considering that 0 means "I do not admire them at all" and 6 means "I admire them a lot." Fusion with religion was measured using the Dynamic Identity Fusion Index (DIFI; Jiménez et al., 2015). This measure displays a figure made of two circles of different sizes on the computer screen. A small circle on the left side of the computer screen represents "the self." A bigger circle on the right side of the screen represents "religion". Participants were asked to move the small circle until it reached the position that best represented their relationship with religion. Higher degrees of overlap of both circles, from 0 to 100, indicate higher levels of fusion. Costly sacrifices for religion were measured with a five-item scale developed specifically for the study supervised by professional 


\begin{tabular}{|c|c|c|c|}
\hline & Admiration & Sacrifices & \\
\hline \multicolumn{4}{|l|}{ Study 1} \\
\hline Fusion & $0.37^{\star \star}$ & - & \\
\hline \multirow[t]{2}{*}{ Sacrifices } & $0.48^{\star \star}$ & $0.54^{\star \star \star}$ & \\
\hline & Cost of sacrifice & Fusion & \\
\hline \multicolumn{4}{|c|}{ Cust o sactilice } \\
\hline Fusion & $0.46^{\star \star}$ & - & \\
\hline Fight die & $0.39^{\star \star}$ & $0.56^{\star \star \star}$ & \\
\hline \multicolumn{4}{|l|}{ Study 3} \\
\hline Fusion & $0.31^{\star \star}$ & - & \\
\hline Fight die & $0.29^{\star \star}$ & $0.60^{\star \star}$ & \\
\hline \multicolumn{4}{|l|}{ Study 4} \\
\hline Fusion & $0.27^{\star \star}$ & - & \\
\hline Fight die & $0.35^{\star \star}$ & $0.53^{\star \star}$ & \\
\hline \multicolumn{4}{|l|}{ Study 5} \\
\hline Fusion & $0.33^{\star \star}$ & & \\
\hline \multirow[t]{2}{*}{ Fight die } & $0.31^{\star \star}$ & $0.58^{\star \star}$ & \\
\hline & Cost of sacrifice & Fusion & Help \\
\hline \multicolumn{4}{|l|}{ Study 6} \\
\hline Fusion & $0.36^{\star \star}$ & - & \\
\hline Help & $0.26^{\star \star}$ & $0.22^{\star \star}$ & - \\
\hline Aggression & $-0.23^{\star \star}$ & $-0.20^{\star \star}$ & $-0.77^{\star \star}$ \\
\hline
\end{tabular}

psychologists that work in prison (for example, "If it was necessary, I would be willing to move to a prison further away from my family to defend my religion", $\alpha=0.96$ ) (see Supplementary Information).

Results and discussion. Table 2 presents the correlations between the variables included in the different studies. We performed a multivariate analysis of variance (MANOVA) on admiration, identity fusion, and costly sacrifices. In line with our predictions, results indicated that jihadists (vs. non-terrorist criminals) reported more admiration toward radical Islamist groups, $F(1,68)=9.27$, $p=0.003, \eta_{\mathrm{p}}^{2}=0.12, \mathrm{Ms}=0.91$ vs. 0.11 , SDs $=1.90$ vs. 0.53 , more fusion with religion, $F(1,68)=17.32, p<0.001, \eta_{\mathrm{p}}^{2}=0.20$, $M s=63.87$ vs. 26.29 , SDs $=40.94$ vs. 38.93 , and more willingness to engage in costly sacrifices for religion in prison, $F(1,68)=19.41$, $p<0.001, \eta_{\mathrm{p}}^{2}=0.222, \mathrm{Ms}=2.61$ vs. $0.61, \mathrm{SDs}=2.43$ vs. 1.27 .

To test our hypothesis that feelings of admiration toward radical Islamist groups and fusion with religion mediate the effect of groups on willingness to perform costly sacrifices for religion in prison, we performed a mediation analysis using Hayes' (2018) PROCESS Macro, Model 6. We included the group $(0=$ nonterrorist criminals, $1=$ jihadists) as the predictor, admiration as the first mediator, identity fusion as the second mediator, and costly sacrifices as the outcome variable. This analysis provided support for the proposed mediation model: Jihadists (vs. nonterrorist criminals) reported greater willingness to engage in costly sacrifices for religion in prison because of greater admiration toward radical Islamist groups and fusion with religion (see Fig. 1).

While Study 1 offers quasi-experimental evidence for our model, Studies 2-6 were conducted to present causal evidence through a series of experimental and longitudinal studies. In these studies, we also examined in greater detail why admiration produces greater identity fusion and self-sacrifices. For the next studies, power analyses were conducted with 5000 Monte Carlo simulations. Assuming small-to-medium effect sizes and power set at 0.80 , a sample of 135 participants were recommended in Studies 2 and 6. A sample size of 215 people were recommended in Studies 3-5.

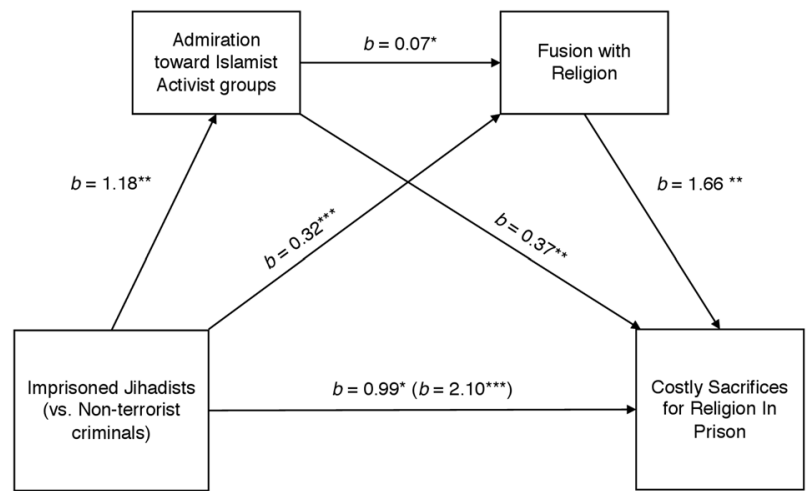

Fig. 1 Linear mediation model in Study $\mathbf{1}(\mathbf{N}=\mathbf{7 1})$. Jihadists expressed more willingness to engage in costly sacrifices for religion in prison via (1) admiration toward radical Islamist groups alone, $b=0.44$, s.e. $=0.25,95 \%$ $\mathrm{Cl}[0.02,0.97]$, (2) fusion with religion alone, $b=0.54$, s.e. $=0.29,95 \% \mathrm{Cl}$ $[0.13,1.22]$, and (3) admiration and fusion serially, $b=0.13$, s.e. $=0.07$, $95 \% \mathrm{Cl}[0.02,0.30]$, (Study 1). Note: ${ }^{\star} p<0.05 ;{ }^{\star \star} p<0.01 ;{ }^{\star \star \star} p<0.001$.

Study 2: Feelings of admiration increase perceived intensity of self-sacrifice, identity fusion, and willingness to fight and die. In line with our theoretical framework that admiration is an emotion elicited by virtue (Cox, 2010; Schnall et al., 2010; Vianello et al., 2010; Vyver and Abrams, 2015), we hypothesized that admiring someone increases the saliency of the costly sacrifices that person made for the group, such that the more intense the perceived sacrifices, the greater the identity fusion with the group, and the willingness to engage in costly behaviours.

\section{Method}

Participants. Participants for this study and the rest of the online studies were recruited using a snowball procedure wherein Psychology students invited their acquaintances to volunteer.

One hundred and fifty-two participants volunteered for this study $\left(M_{\mathrm{age}}=39.62, \mathrm{SD}_{\mathrm{age}}=13.89,65.1 \%\right.$ women $)$.

Procedure. The study used an experimental design. After obtaining participants' informed consent, participants were randomly assigned to one of two experimental conditions. In the admiration condition $(n=76)$ participants were asked to think about a person from their country they admire and write about who this person is and the reasons for admiring him/her. In the typical condition $(n=76)$, participants were asked to think about a typical citizen of their country and to describe that person. After that, participants completed our outcome variables and the manipulation check.

As a manipulation check, feelings of admiration were measured with a four-item scale developed for the study (for example, "I admire this person's actions", $\alpha=0.91$ ) in all studies. The results confirmed that our manipulations were successful (see Supplementary Information).

Cost of personal sacrifice was measured with a five-item scale developed for the study (for example, "This person incurs a great loss to further the interests of my country", $\alpha=0.78$ ).

Fusion with the country was measured with the seven-item verbal measure of fusion developed by Gómez et al. (2011a); for example, "I am one with my country", $\alpha=0.86$.

Willingness to fight and die for the country was measured with a seven-item scale (Swann et al., 2019; for example, "Hurting other people is acceptable if it means protecting my country", $\alpha=0.83$ ).

Lastly, participants' level of fusion with groups unrelated to the manipulation (their family, France, Portugal, and Italy) was measured with the DIFI adapted to these groups. In this and the 
Table 3 Means and standard deviations per condition for Studies 2-6.

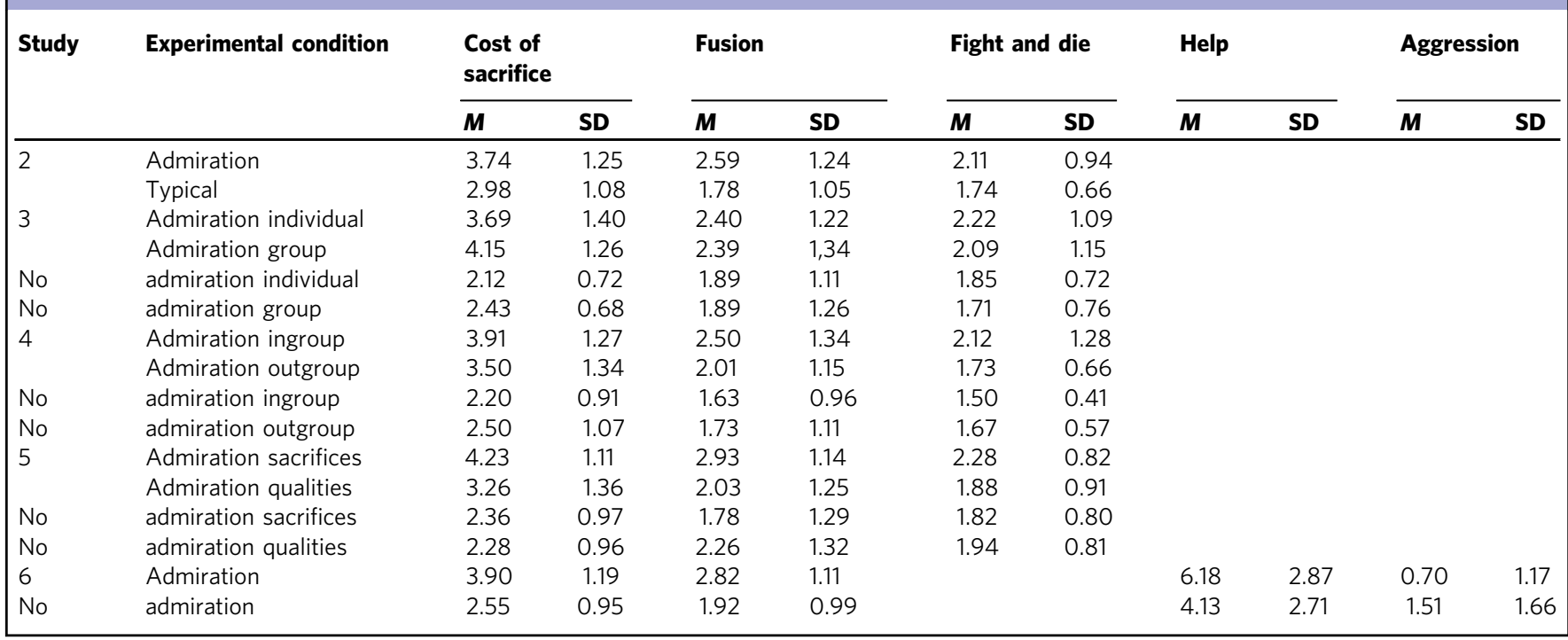

following studies, the effects of our manipulations on fusion with groups different from Spain were not significant, showing that the strategies that we used to induce admiration did not increase identity fusion indiscriminately (see Supplementary Information).

Results and discussion. A multivariate analysis of variance (MANOVA) showed that participants in the admiration (vs. typical) condition perceived the ingroup member's sacrifices as more intense, $F(1,150)=16.31, p<0.001, \eta_{\mathrm{p}}^{2}=0.10$, felt more fused with their country, $F(1,150)=18.77, p<0.001, \eta_{\mathrm{p}}^{2}=0.11$, and were more willing to fight and die for it, $F(1,150)=7.78, p=0.006, \eta_{\mathrm{p}}^{2}=0.05$ (see Table 3 to obtain more information about the means and standard deviations per condition of Studies 2-6).

To test our hypothesis that cost of sacrifice and identity fusion serially mediate the effect of the experimental condition on willingness to fight and die for the country, we used PROCESS macro, Model 6 . Condition $(0=$ typical, $1=$ admiration $)$ was included as the predictor, cost of sacrifice as the first mediator, identity fusion as the second mediator, and willingness to fight and die as the outcome variable. Results indicated that admiration for an ingroup member produced greater willingness to fight and die for the country through its influence on the perceived intensity of sacrifices and identity fusion (see Fig. 2). In the next study we explored whether admiration toward a group of people rather than specific individuals would produce similar effects.

Study 3: Feelings of admiration toward an individual versus a group. Study 3 was conducted to clarify whether admiration toward a group of fellow countrymen or admiration toward a single compatriot, increases willingness to fight and die for the country through perceived intensity of sacrifices and identity fusion.

\section{Method}

Participants. Two hundred and thirty-one participants $\left(M_{\text {age }}=39.76, \mathrm{SD}_{\mathrm{age}}=13.69,61.9 \%\right.$ women $)$ volunteered for this study.

Procedure. Study 3 featured an experimental 2 (no admiration vs. admiration) $\times 2$ (individual vs. group) design. After obtaining participants' informed consent, participants were randomly assigned to one of four experimental conditions. In the individual

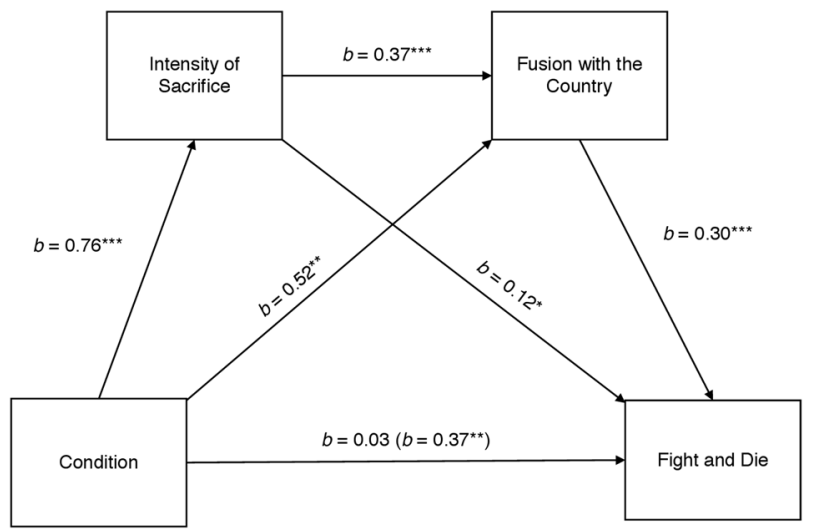

Fig. 2 Linear mediation model in Study $2(\boldsymbol{N}=\mathbf{1 5 2})$. Admiration for an ingroup member increased willingness to fight and die via (1) intensity of sacrifices alone, $b=0.10,95 \% \mathrm{Cl}[0.03,0.20]$, (2) identity fusion alone, $b=0.16,95 \% \mathrm{Cl}[0.05,0.30]$, and (3) intensity of sacrifice and fusion with country serially, $b=0.08,95 \% \mathrm{Cl}[0.03,0.17]$. (Study 2 ). Note: ${ }^{\star} p<0.05$; ${ }^{\star *} p<0.01 ;{ }^{* \star} p<0.001$.

admiration condition $(n=52)$, participants were asked to think about a person from their country they admire and write about him/her as in Study 2. In the no admiration individual condition $(n=59)$, participants were asked to think about a person of their country they do not admire and to write about who this person is and the reasons for their lack of admiration. Participants in the group admiration condition $(n=65)$, and the group no admiration condition $(n=55)$ received similar instructions, but they were asked to think about a group of people from their country instead of a person. Then, participants were asked to complete the same measures as in Study 2 adapted to the individual or group conditions: admiration toward the person or group they thought about $(\alpha=0.96)$, perceived cost of the personal sacrifice $(\alpha=0.66)$, their fusion with the country $(\alpha=0.87)$, willingness to fight and die for the country $(\alpha=0.84)$, and fusion with other groups.

Results and discussion. A 2 (no admiration vs. admiration) $\times 2$ (individual vs. group) MANOVA on the outcome measures yielded significant main effects of admiration. In the admiration 


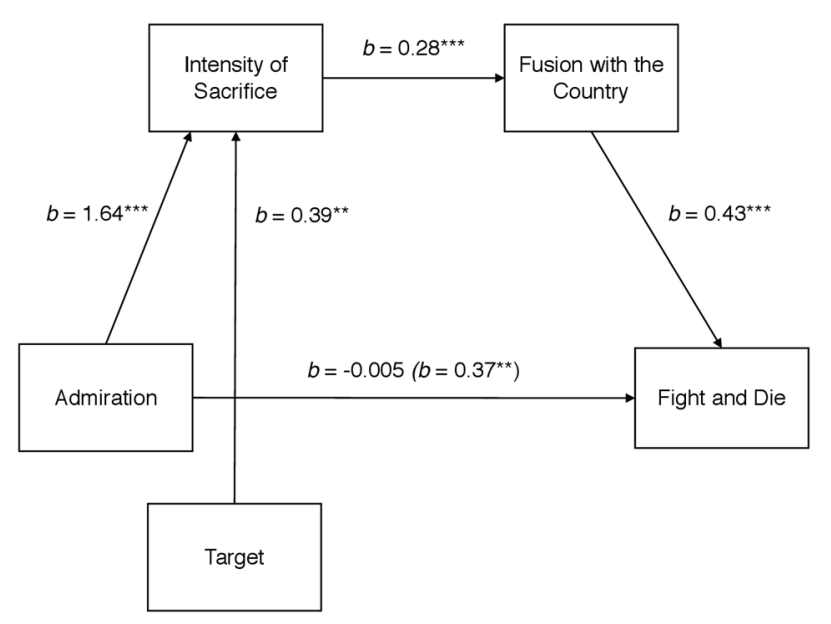

Fig. 3 Linear mediation model in Study $3(\boldsymbol{N}=\mathbf{2 3 1})$. Admiration increased willingness to fight and die for the country via intensity of sacrifice and fusion serially, $b=0.20,95 \% \mathrm{Cl}[0.09,0.33]$. However, admiration did not influence willingness to fight and die via intensity of sacrifices alone, $b=0.16,95 \% \mathrm{Cl}[-0.004,0.32]$, or identity fusion alone, $b=0.01,95 \% \mathrm{Cl}$ $[-0.14,0.18]$. Note. ${ }^{\star} p<0.05 ;{ }^{\star \star} p<0.01 ;{ }^{\star \star} p<0.001$.

(vs. no admiration) conditions, participants perceived the ingroup member's sacrifices as more intense, $F(1,227)=135.98, p<0.001$, $\eta_{\mathrm{p}}^{2}=0.37$, felt more fused with their country, $F(1,227)=9.38$, $p=0.002, \eta_{\mathrm{p}}^{2}=0.04$, and were more willing to fight and die for it, $F(1,227)=8.48, p=0.004, \eta_{\mathrm{p}}^{2}=0.04$. The analysis on cost of sacrifice also revealed a significant main effect of target of admiration indicating that participants in the group (vs. individual) conditions perceived the ingroup members' sacrifices as more intense, $F(1,227)=7.76, p=0.006, \eta^{2}{ }_{p}=0.03$. No other effects were significant, $p s=0.305$ (see the statistics for the main effects of all studies in Supplementary Information).

To test our mediational hypothesis that cost of sacrifice and identity fusion would serially mediate the effect of admiration on willingness to fight and die for the country, we performed a serial mediation analysis as in Study 2. As expected, admiration increased willingness to fight and die for the country through its influence on intensity of sacrifices and identity fusion.

Consistent with expectations from prior research on fusion (Gómez et al., 2011a, 2020; Swann et al., 2009), the analyses showed the effects were not moderated by whether admiration was experienced toward a group or an individual (see Fig. 3). However, the impact of admiration could vary depending on whether or not the admired person belongs to the ingroup.

Study 4: Feelings of admiration toward an ingroup versus an outgroup member. Study 4 analysed whether the direct and indirect effects of admiration on willingness to fight and die for the group are moderated by the group membership of the admired person.

\section{Method}

Participants. Two hundred and fifty-three participants $\left(M_{\text {age }}=38.11, \quad \mathrm{SD}_{\mathrm{age}}=13.41,68 \%\right.$ women $)$ volunteered for this study.

Procedure. Study 4 featured an experimental 2 (no admiration vs. admiration $) \times 2$ (ingroup vs. outgroup) design. Participants were randomly assigned to one of four experimental conditions. In the ingroup admiration condition $(n=68)$, participants were asked to think about a person of their country they admire. In the ingroup no admiration condition $(n=60)$, participants were asked to think about a person of their country they do not admire. In the outgroup admiration condition $(n=66)$, participants were asked to think about a person they admire from another country. In the outgroup no admiration condition $(n=59)$, participants were asked to think about a person of a different country they do not admire. In all cases, participants were asked to write about who that person is and the reasons for admiring (or not admiring) that person. Then, we measured participants' admiration toward the person they thought about $(\alpha=0.94)$, the perceived cost of the sacrifice for the country attributed to him/her $(\alpha=0.68)$, their fusion with the country $(\alpha=0.84)$, their willingness to fight and die for the country $(\alpha=0.82)$, and their fusion with other groups. These variables were assessed as in Studies 2 and 3.

Results and discussion. A 2 (no admiration vs. admiration) $\times 2$ (ingroup vs. outgroup) MANOVA revealed significant interactions on intensity of the sacrifices, $F(1,249)=5.80, p=0.017$, $\eta_{p}^{2}=0.02$, fusion $F(1,249)=4.17, p=0.042, \eta_{p}^{2}=0.02$, and willingness to fight and die for the country, $F(1,249)=6.99$, $p=0.009, \eta_{p}^{2}=0.03$. The effects of admiration were higher in the ingroup condition than in the outgroup condition: $F(1$, $249)=68.20, \quad p<0.001, \quad \eta_{p}^{2}=0.22$, vs. $F(1,249)=22.82$, $p<0.001, \eta_{p}^{2}=0.08$, for cost of the sacrifices; $F(1,249)=17.86$, $p<0.001, \eta^{2}{ }_{p}=0.07$, vs. $F(1,249)=1.71, p=0.193, \eta^{2} p=0.01$, for identity fusion; and, $F(1,249)=18.00, p<0.001, \eta^{2} p=0.07$, vs. $F(1,249)=0.23, p=0.633, \eta_{p}^{2}=0.00$, for willingness to fight and die for the country. That is, participants in the admiration conditions perceived higher intensity of the sacrifices, felt more fused with their country and were more willing to fight and die for it than those in the no admiration conditions. However, those differences were weaker when participants thought about outgroup members than when they thought about ingroup members.

To test our hypothesis that cost of sacrifice and identity fusion mediate the interactive effect of admiration and group on willingness to fight and die for the country, we performed a moderated serial mediation analysis using PROCESS macro, Model 85 . We included level of admiration $(0=$ no admiration, 1 $=$ admiration $)$ as the predictor, group $(0=$ outgroup, $1=$ ingroup) as the moderator, cost of sacrifice and identity fusion (centred) as the first and second mediators, respectively, and willingness to fight and die as the outcome variable. Results revealed that in the ingroup conditions, admiration influenced willingness to fight and die through its influence on intensity of sacrifice and fusion with country. In the outgroup conditions, the indirect effect was also significant, but weaker than in the ingroup conditions (see Fig. 4).

So far, we have shown that feeling of admiration for one or more ingroup members increases the willingness to engage in pro-group behaviours. In the next study, we examine whether admiring someone for a specific reason influence this motivational process.

Study 5: Feelings of admiration due to self-sacrifice versus personal qualities. Study 5 examined whether admiration exerts different effects on pro-group behavioural tendencies depending on whether it is due to the personal qualities of the admired person or to his/her sacrifices for the country.

\section{Method}

Participants. Two hundred and forty-one participants $\left(M_{\text {age }}=36.58, \mathrm{SD}_{\text {age }}=13.52,63.1 \%\right.$ women $)$ volunteered for this study. 


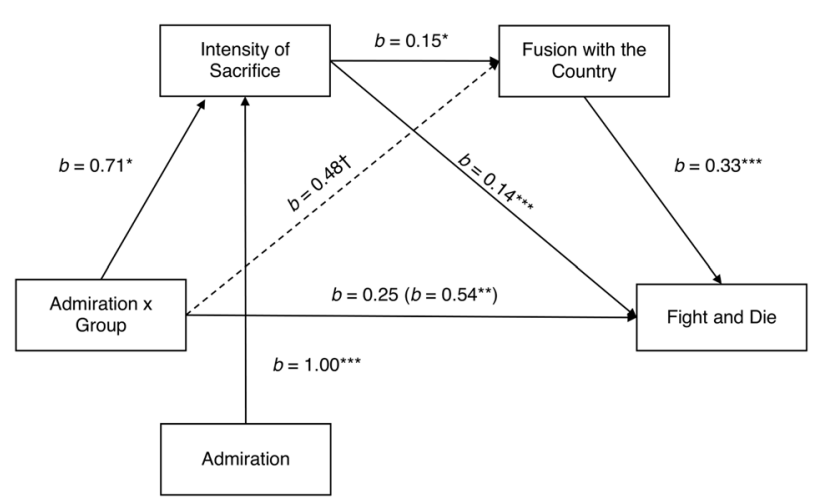

Fig. 4 Linear mediation model in Study $4(\boldsymbol{N}=\mathbf{2 5 3})$. In the ingroup conditions, level of admiration influenced willingness to fight and die via 1) intensity of sacrifice alone, $b=0.24,95 \% \mathrm{Cl}[0.10,0.40]$, (2) identity fusion alone, $b=0.20,95 \% \mathrm{Cl}[0.06,0.36]$, and (3) intensity of sacrifices and fusion with country serially, $b=0.09,95 \% \mathrm{Cl}[0.01,0.20]$. In the outgroup conditions, level of admiration influenced willingness to fight and die via (1) intensity of sacrifice alone, $b=0.14,95 \% \mathrm{Cl}[0.05,0.25]$, and (2) intensity of sacrifices and fusion with country serially, $b=0.05,95 \% \mathrm{Cl}$ $[0.005,0.12]$. The indirect effect via identity fusion alone was not significant, $b=0.04,95 \% \mathrm{Cl}[-0.10,0.17]$. In the outgroup conditions, the indirect effect was also significant, but weaker than in the ingroup conditions, $b=0.10,95 \% \mathrm{Cl}[0.02,0.21]$. Note: ${ }^{\star} p<0.05 ;{ }^{\star \star} p<0.01$; ${ }^{\star \star \star} p<0.001$.

Procedure. Study 5 featured an experimental 2 (no admiration vs. admiration) $\times 2$ (personal qualities vs. personal sacrifices for the group) design. After obtaining participants' informed consent, participants were randomly assigned to one of four experimental conditions. In the admiration or no admiration for personal sacrifices conditions ( $n \mathrm{~s}=42$ and 65 ), participants were asked to think about a person of their country they admire or do not admire because of the sacrifices he/she makes for it. In the admiration or not admiration for personal qualities conditions ( $n s=64$ and 69), participants were asked to think about a person from their country they admire or do not admire due to their personal characteristics. In all cases, participants were asked to specify who this person is and the reasons for admiring or not that person. Then, participants were asked to complete measures of their level of admiration toward the person they thought about $(\alpha=0.95)$, the perceived cost of the sacrifice for the country attributed to him/her $(\alpha=0.70)$, their fusion with the country $(\alpha=0.87)$, their willingness to fight and die for the country $(\alpha=0.78)$, and their fusion with other groups as in Studies 2-4.

Results and discussion. A 2 (no admiration vs. admiration) $\times 2$ (personal qualities vs. personal sacrifices for the group) MANOVA revealed significant interactions on intensity of sacrifices, $F$ $(1,236)=9.19, p=0.003, \eta^{2}{ }_{p}=0.04$, identity fusion, $F(1$, $236)=17.07, p<0.001, \eta_{\mathrm{p}}^{2}=0.07$, and willingness to fight and die for the country, $F(1,236)=5.54, p=0.019, \eta_{\mathrm{p}}^{2}=0.02$. Specifically, the effects of admiration were greater in the personal sacrifices than in the personal qualities condition: $F(1$, $236)=71.88, \quad p<0.001, \quad \eta_{p}^{2}=0.23, \quad$ vs. $\quad F(1,236)=25.71$, $p<0.001, \eta_{\mathrm{p}}^{2}=0.10$, for cost of sacrifice; $F(1,236)=20.87, p<$ $0.001, \eta_{\mathrm{p}}^{2}=0.08$ vs. $F(1,236)=1.11, p=0.292, \eta_{\mathrm{p}}^{2}=0.01$, for fusion with the country; and, $F(1,236)=7.95, p=0.005$, $\eta_{p}^{2}=0.03$ vs. $F(1,236)=0.13, p=0.723, \eta_{p}^{2}=0.00$, for willingness to fight and die for it. That is, participants in the admiration for personal sacrifices condition perceived higher intensity of the sacrifices, felt more fused with their country and were more willing to fight and die for it than those in the no

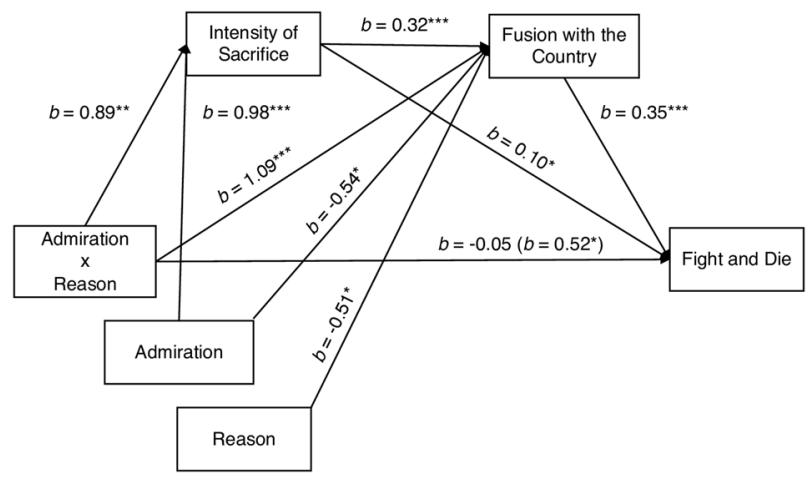

Fig. 5 Linear mediation model in Study $4(\boldsymbol{N}=\mathbf{2 4 1})$. In the personal sacrifice conditions, admiration influenced willingness to fight and die via (1) intensity of sacrifice alone, $b=0.19,95 \% \mathrm{Cl}[0.02,0.37]$, (2) identity fusion alone, $b=0.19,95 \% \mathrm{Cl}[0.01,0.38]$, and (3) intensity of sacrifices and identity fusion serially, $b=0.21,95 \% \mathrm{Cl}[0.11,0.33]$. In the personal qualities conditions, admiration influenced willingness to fight and die via (1) intensity of sacrifice alone, $b=0.10,95 \% \mathrm{Cl}[0.01,0.21]$, (2) identity fusion alone, $b=-0.19,95 \% \mathrm{Cl}[-0.35,-0.04]$, and (3) intensity of sacrifices $\times$ and identity fusion serially, $b=0.11,95 \% \mathrm{Cl}[0.05,0.19]$. The effect in the quality's condition was smaller than in the personal sacrifice condition, $b=0.09,95 \% \mathrm{Cl}[0.01,0.21]$. Note: ${ }^{\star} p<0.05 ;{ }^{\star \star} p<0.01 ;{ }^{\star \star \star} p<$ 0.001 .

admiration for personal sacrifices condition. However, those differences were weaker or non-significant when participants thought about personal qualities.

To test our hypothesis that cost of sacrifice and identity fusion would mediate the interactive effect of admiration and reason on willingness to fight and die for the country, we performed a moderated serial mediation analysis as in Study 4, but considering reasons of admiration ( $0=$ personal qualities, $1=$ sacrifices $)$ as the moderator. Results revealed that in both the personal qualities and personal sacrifices conditions, admiration influenced willingness to fight and die through its influence on intensity of sacrifices and fusion with country. However, the effect in the personal qualities condition was smaller than in the personal sacrifices condition (see Fig. 5).

Studies 1-5 examined the behavioural tendencies associated to admiration rather than actual behaviour. We solved this limitation in a final study conducted in two waves that additionally tested the temporal stability of the effects of admiration.

Study 6: Long-lasting effects of admiration on real behaviour. The last study extends previous results in two ways: it provides evidence of the effects of admiration over time and focuses on actual pro-group behaviour.

\section{Method}

Participants. Seven hundred and seventy-one participants $\left(M_{\text {age }}=36.26, \mathrm{SD}_{\text {age }}=12.91,56.7 \%\right.$ women $)$ took part in the first wave and 376 participants $\left(M_{\text {age }}=37.29, \mathrm{SD}_{\text {age }}=13.59,52.9 \%\right.$ women) also completed the second wave.

Procedure. This study consisted of a longitudinal experimental design. In the first wave, participants were randomly assigned to the admiration $(n=391)$ or the no admiration condition $(n=380)$ as in Study 5 (personal sacrifices conditions). Then, we measured their feelings of admiration $(\alpha=0.95)$, the perceived cost of the sacrifice for the country attributed to the person they thought about $(\alpha=0.70)$, and their level of fusion with their country $(\alpha=0.83)$ with the same scales used in Studies $2-5$. We 
told participants that they would be contacted one month after wave 1 to participate in the second wave.

In the second wave, we used an adaptation of the tangram help/hurt task to measure participants' actual behaviour toward an ingroup member (Saleem et al., 2015). Participants were presented with a total of 30 different tangram puzzles that could be classified depending on their level of difficulty: 10 were easy, another 10 were difficult, and the remaining 10 were of medium difficulty. Participants were asked to assign 11 of these tangrams to another (fictitious) participant from their country, so that he/ she could solve them in $<10 \mathrm{~min}$. We told participants that the other person could win a $€ 25$ voucher if he/she completed 10 tangrams in $<10 \mathrm{~min}$, otherwise the person would not receive anything. Following the indications of Saleem et al. (2015), we calculated a measure of helping behaviour, operationalised as the number of easy tangrams assigned by participants $>1$, and a measure of aggressive behaviour, operationalised as the number of difficult tangrams assigned $>1$. Attrition analyses showed that participants who took part in both waves were significantly less fused than participants who only took part in the first wave (see Supplementary Information).

Results and discussion. In the first wave, a MANOVA indicated that participants in the admiration (vs. no admiration) condition perceived the ingroup member's sacrifices as more intense, $F$ $(1769)=303.76, p<0.001, \eta^{2}{ }_{p}=0.28$, and were more fused with the group, $F(1769)=141.08, p<0.001, \eta^{2}{ }_{p}=0.16$.

In the second wave, a mixed analysis of variance (ANOVA) with condition as a between-subject factor $(0=$ no admiration, 1 $=$ admiration) and behaviour (helping vs. aggression) as a withinsubject factor showed a significant condition $\times$ behaviour interaction, $F(1374)=48.34, p<0.001, \eta_{p}^{2}=0.11$. Results showed that participants engaged in more helping than aggressive behaviour, but such difference was higher in the admiration condition, $F(1,374)=383.87, p<0.001, \quad \eta^{2}=0.67 \quad$ (mean difference $=5.48, \mathrm{SD}=0.28, p<0.001)$, than in the no admiration condition, $F(1374)=76.13, p<0.001, \eta_{p}^{2}=0.29$ (mean difference $=2.63, \quad \mathrm{SD}=0.30, \quad p<0.001)$. Follow-up analyses revealed that the effect of condition on helping behaviour was bigger (mean difference $=2.05, \quad \mathrm{SD}=0.29, \quad p<0.001), \quad F$ $(1374)=50.45, p<0.001, \eta^{2}=0.12$, than the effect of condition on aggressive behaviour (mean difference $=-0.81, \mathrm{SD}=0.15$, $p<0.001), F(1374)=29.75, p<0.001, \eta^{2}=0.07$.

To test our hypotheses that intensity of sacrifice and identity fusion in Wave 1 would mediate the effects of condition on helping and aggressive behaviour in Wave 2, we performed two mediation analyses using PROCESS macro, Model 6. For bothhelping and aggressive behaviour-the experimental condition influenced behaviour through its influence on intensity of sacrifices and identity fusion (see Fig. 6).

\section{General discussion}

In field and online studies, we found that admiration is an emotion that makes individuals feel viscerally connected to their group or convictions, which in turn influences them to engage in costly sacrifices for their comrades or deep-seated beliefs. This effect was robust: it replicated across a variety of research designs (cross-sectional, experimental, and longitudinal), samples (terrorist and non-terrorist), and operationalizations of self-sacrifice (self-report and behaviour). In the prisons of Spain, for instance, the jihadists we surveyed expressed greater admiration for radical Islamist groups than non-jihadist Muslims, and such experience was positively related to identity fusion and costly sacrifices for religion in prison. Five experiments provided additional support for this model and illuminated the conditions under which

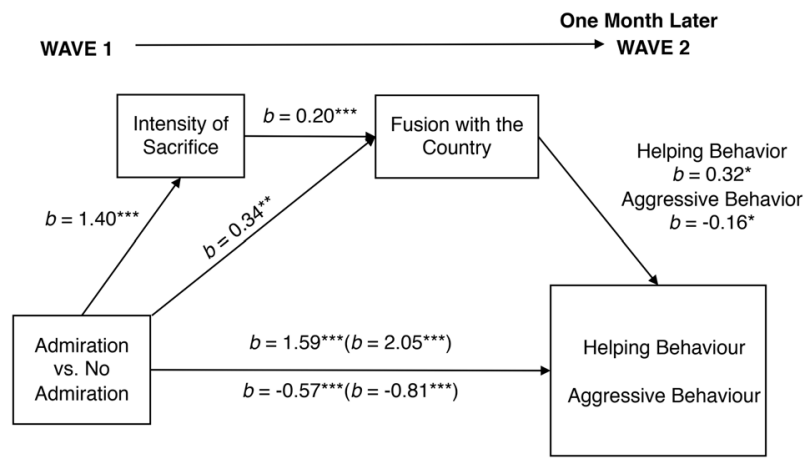

Fig. 6 Linear mediation model in Study $6(N=771$ vs. 376 for waves 1 and 2, respectively). For helping behaviour, condition influenced helping behaviour via (1) identity fusion alone, $b=0.11,95 \% \mathrm{Cl}[0.01,0.25]$, (2) intensity of the sacrifice alone, $b=0.57,95 \% \mathrm{Cl}[0.07,1.05]$, and (2) intensity of sacrifice and fusion with country serially, $b=0.09,95 \% \mathrm{Cl}$ $[0.003,0.07]$. For aggressive behaviour, condition influenced aggressive behaviour via (1) identity fusion alone, $b=-0.07,95 \% \mathrm{Cl}[-0.16,-0.01]$, (2) intensity of the sacrifice alone, $b=-0.36,95 \% \mathrm{Cl}[-0.64,-0.09]$, and (3) intensity of sacrifice and fusion with country serially, $b=-0.06,95 \%$ $\mathrm{Cl}[-0.12,-0.01]$. Note. ${ }^{\star} p<0.05 ;{ }^{\star \star} p<0.01 ;{ }^{\star \star \star} p<0.001$.

admiration produces greater identity fusion and costly sacrifices. Together, these findings reveal how admiration may lead people down a path toward extremism, and offer a number of important theoretical and practical implications.

First, admiration for a person or a group produces a chain reaction culminating in individuals making sacrificial behaviours for their ideological convictions. Admiration produces this effect by rendering cognitively salient the sacrifices peers have made for the group-a relationship that has not been documented in previous work. As we consistently showed, the more these sacrifices are perceived as costly, the more people feel fused with their ideological convictions or with their group, and the greater their willingness to fight and die for it. Thus, these results reinforce the notion that admiration is an other-praising emotion connected to virtue (Algoe and Haidt, 2008; Onu et al., 2016) and explain the psychological process through which admiration galvanizes individuals to make self-sacrifices.

Second, admiration produces changes in the self. This finding is important given that prior research has been relatively quiet on the role of emotions in promoting identity fusion. While research has indicated that, in particular, sharing intense dysphoric experiences with other group members causes identity fusion (Jong et al., 2015; Páez et al., 2015; Segal et al., 2018), we show that there are also positive emotions that can enhance the sense of oneness with the group. Importantly, such experience does not necessarily need to be shared with other groups members to produce its effects. Furthermore, given that admiration has been a topic traditionally examined through the lens of positive psychology, it has been widely assumed that admiration invariably produces positive effects on intergroup relationships (Onu et al., 2016). The present research challenges this assumption by showing that admiration has a darker side, and can make individuals more prone to defending the group they cherish at all costs, including through violence. This suggests that admiration, commonly a catalyst for good deeds, can also inspire malevolent actions.

Third, we establish the multiple boundary conditions under which admiration increases identity fusion and greater willingness to fight and die for a group or a set of convictions. For instance, previous work has shown that strongly fused individuals are just as willing to self-sacrifice for one ingroup member as they 
are for five ingroup members (Swann et al., 2014). The present research builds on these findings with evidence that the effect of admiration on the intensity of perceived sacrifices, identity fusion, or willingness to fight and die for the group is not moderated by the number of ingroup members being admired.

In parallel, we also demonstrate that admiration for both ingroup and outgroup members is positively related to people's willingness to fight and die for their group through perceived sacrifices and identity fusion. Although the effect was significantly stronger when admiring an ingroup member, these results suggest that admiration fuels sacrifices even if it occurs in relation to a group that one does not belong to-a finding that warrants further investigation. Additionally, we show that the factors giving rise to admiration are important in this process. Admiring someone for their group sacrifices yields stronger levels of identity fusion and willingness to fight and die for the group than when admiration is related to the subject's personal qualities. This finding is consistent with research indicating that admiration produced by moral actions (sacrifices) - also referred to as moral elevation-versus non-moral actions (skills and talents) is more strongly associated with prosocial tendencies (Algoe and Haidt, 2009).

Fourth, admiration for an ingroup member produces measurable behavioural changes for as long as one month after experiencing this emotion. In this sense, our results are consistent with research showing that moral elevation produces altruistic behaviour (Aquino et al., 2011; Schnall et al., 2010). However, our findings extend prior work in several ways. For starters, we demonstrate the psychological mechanisms through which this phenomenon occurs, namely (1) perceived intensity of sacrifices and (2) identity fusion. Next, by demonstrating that admiration for a specific ingroup member increases prosocial behaviourand decreases aggression-toward other ingroup members, we show that the emotional effect generalizes to other group members as well. Finally, the results indicate that admiration has relatively long-term consequences that go beyond momentarily priming in an experimental context.

Collectively, our findings support the notion that admiration plays a key role in fostering the emulation of ideals embodied by models of virtue (Algoe and Haidt, 2009; Onu et al., 2016). It does so by increasing the salience of other people's sacrifices, which then produces important changes in identity by aligning the personal self with the collective self. This in turn makes individuals prone to engage in personal costly sacrifices for their ingroup or their convictions.

The preceding results yield important practical implications relevant to preventing and countering violent extremism. For instance, our research suggests that expressing admiration for individuals or groups endorsing violence might be a precursor to radicalization. This finding is particularly relevant where online radicalization is accelerated by propaganda videos conspicuously designed to attract new followers with a narrative intended to produce sympathy and admiration for their members.

Ensuring that individuals, especially youths, have access to prosocial groups (such as sports teams, youth centres, and volunteer organizations) and inspiring role models might be an effective strategy to steer people away from radical organizations. Although this may seem obvious to seasoned practitioners, the signs of radicalization are not always clear to parents, teachers, and community members. Making information more widely available could lead people to seek professional help in a timely fashion (Bélanger, 2017).

Additionally, our research may be useful for designing deradicalization strategies in which the primary goal is to redirect violent extremist offenders away from engaging in or supporting violent activities (Kruglanski et al., 2014; Webber et al., 2018).
Our results indicate that jihadists' admiration for terrorist groups is one important predictor of their willingness to engage in extreme behaviour in prison. Given that admiration is in part a moral emotion, one potential strategy to undermine this feeling would be to subvert the radical group's moral stature, for example, by highlighting the inconsistencies between its "moral code" (establishing a caliphate for Muslims) and its behaviours (mass executions of Muslims). Case studies have shown that a large proportion of defectors arrive at these disillusionments on their own (Bjørgo, 2011; Bjørgo and Horgan, 2009). However, additional research is needed to examine how this strategy can be implemented systematically to catalyse attitudinal change in violent extremist offenders.

Notwithstanding the role of admiration in violent extremism, our research should be understood in a broader context, as it is well documented that admiration also produces positive effects on intergroup relationships (Onu et al., 2016; Schnall et al., 2010; Vyver and Abrams, 2015). Moreover, admiring individuals or groups making costly sacrifices for the common good can be an important vector of long-lasting social change through nonviolence. For example, in 2019, the environmental activist Greta Thunberg galvanized young climate activists worldwide by skipping school on Fridays to protest in front of the Swedish Parliament for stricter environmental regulations. Her sacrifices culminated in what the editors of Time magazine said was the creation of "a global attitudinal shift, transforming millions of vague, middle-of-the-night anxieties into a worldwide movement calling for urgent change (Time, 2019)." More recently, people around the world have cheered healthcare professionals heading to work as they risk their lives to save those infected during the COVID-19 pandemic. It could well be that admiration for these modern-day heroes is motivating others to make personal sacrifices (such as self-isolation and social-distancing) to "flatten the curve" and help their country recover.

Our studies have several limitations as well. First, we have tested our model with Islamic terrorists and the general population. Although there is a solid rationale to suppose that the same processes would apply to other groups such as social activists or non-religious terrorists, future studies should test the validity of our theoretical model with different samples. Second, classic socio-psychological research has consistently shown that the probability of success of social influence attempts increases as the number of people who hold an opinion or engage in a certain behaviour augment (Cialdini and Griskevicius, 2019; Cialdini and Sagarin, 2005). In contrast, our results show that the effects of admiration on identity fusion and pro-group behaviour do not vary as a function of the number of individuals toward whom admiration is felt. Identity fusion is based on the experience of strong relational ties with other group members and we believe that this fact may explain our results, but further research is needed to find out if that is the case. Third, several studies suggest that positive mood might drive individuals to engage in prosocial behaviours (e.g. Baron, 1997; North et al., 2004; Salovey et al., 1991). Feeling admiration is a mood enhancer (Algoe and Haidt, 2009; Onu et al., 2016) and, although a high number of studies have demonstrated that the effects of admiration cannot be reduced to those of other positive emotional states (Pohling and Diesner, 2016), future studies should include measures of mood and other positive emotions and control for these variables.

\section{Conclusions}

Fighting violent extremism is a collective effort which requires understanding the motives that drive some individuals to fight, die, and even kill for a group or a set of convictions. Here, we show that admiration enables collective engagement by bringing to mind the 
sacrifices others have made for the group, which in turn produces a union between the personal and the social self. The costlier the sacrifices, the greater the identity fusion with other group members, even when the admiration stems from the sacrifices of outgroup members. What's more, intensified identity fusion due to admiration of an ingroup member increases prosocial behaviour toward other ingroups members. Taken together, the present research suggests that admiration is an emotion intimately related to self-sacrifice, which has important implications for group processes, including social transmission and cooperation.

\section{Data availability}

The data generated during and/or analysed during the current studies are not publicly available due to the type of sample that took part in Study 1 and the potentially negative consequences that could arise from its publication. All data, codes, and materials are available from the corresponding author upon reasonable request.

Received: 11 June 2020; Accepted: 5 February 2021;

Published online: 01 March 2021

\section{References}

Admiration. Oxford English Dictionary (2020). http://www.oed.com/view/Entry/ 2566. Accessed 28 May 2020

Aquino K, Mcferran B, Laven M (2011) Moral identity and the experience of moral elevation in response to acts of uncommon goodness. J Pers Soc Psychol 100 (4):703-718. https://doi.org/10.1037/a0022540

Algoe SB, Haidt J (2009) Witnessing excellence in action: the 'other-praising' emotions of elevation, gratitude, and admiration. J Posit Psychol 4 (2):105-127. https://doi.org/10.1080/17439760802650519

Ashokkumar A, Galaif M, Swann WB (2019) Tribalism can corrupt: why people denounce or protect immoral group members. J Exp Soc Psychol 85:103874. https://doi.org/10.1016/j.jesp.2019.103874

Atran S (2019) The Islamic State's lingering legacy among young men from the Mosul Area. Combating Terrorism Center at West Point. http://ctc.usma. edu/islamic-states-lingering-legacy-among-young-men-mosul-area/. Published January 17, 2019. Accessed 14 May 2020

Baron RA (1997) The sweet smell of...helping: effects of pleasant and ambient fragances on prosocial behavior in shopping malls. Pers Soc Psychol Bull 23:498-503. https://doi.org/10.1177/0146167297235005

Baumeister RF, Leary MR (1995) The need to belong: desire for interpersonal attachments as a fundamental human motivation. Psychol Bull 117 (3):497-529. https://doi.org/10.1037/0033-2909.117.3.497

Bélanger JJ (2017) The rise and fall of violent extremism: the science behind community-based interventions. In: Köpetz C, Fishbach A (Eds.) The motivation-cognition interface; from the lab to the real world. Routledge, New York, pp. 170-195

Bélanger JJ, Caouette J, Sharvit K, Dugas M (2014) The psychology of martyrdom: making the ultimate sacrifice in the name of a cause. J Pers Soc Psychol 107 (3):494-515. https://doi.org/10.1037/a0036855

Bélanger JJ, Moyano M, Muhammad H et al. (2019) Radicalization leading to violence: a test of the $3 \mathrm{~N}$ model. Front Psychiatry 10. https://doi.org/10.3389/ fpsyt.2019.00042

Bélanger JJ, Schumpe BM, Menon B, Conde J, Nociti N (2018) Self-Sacrifice for a Cause: a review and an integrative model. In V. Zeigler-Hill \& T.K. Shackelford (Eds), The Sage Handbook of Personality and Individual Differences

Besta T, Gómez Á, Vázquez A (2014) Original article Readiness to deny group's wrongdoing and willingness to fight for its members: the role of Poles' identity fusion with the country and religious group. Curr Iss Pers Psychol 1:49-55. https://doi.org/10.5114/cipp.2014.43101

Bjørgo T (2011) Dreams and disillusionment: engagement in and disengagement from militant extremist groups. Crime Law Soc Chang 55(4):277-285. https:// doi.org/10.1007/s10611-011-9282-9

Bjørgo T, Horgan J (2009) Leaving terrorism behind: individual and collective disengagement. Routledge

Buhrmester MD, Fraser WT, Lanman JA, Whitehouse H, Swann WB (2014) When terror hits home: identity fused Americans who saw Boston bombing victims as "Family" provided aid. Self Identity 14(3):253-270. https://doi.org/ $10.1080 / 15298868.2014 .992465$
Buhrmester MD, Gómez Á, Brooks ML, Morales JF, Fernández S, Swann WB (2012) My groups fate is my fate: identity-fused Americans and Spaniards link personal life quality to outcome of 2008 elections. Basic Appl Soc Psychol 34(6):527-533. https://doi.org/10.1080/01973533.2012.732825

Buhrmester MD, Newson M, Vázquez A, Hattori WT, Whitehouse H (2018) Winning at any cost: identity fusion, group essence, and maximizing ingroup advantage. Self Identity 17(5):500-516. https://doi.org/10.1080/15298868.2018.1452788

Cialdini RB, Griskevicius V (2019) Social influence. In: Finkel EJ, Baumeister RF (eds) Advanced social psychology. The state of the science, 2nd edn. Oxford University Press, New York, pp. 385-417

Cialdini RB, Sagarin B (2005) Principles of interpersonal influence. In: Brock TC, Brock, Green MC (eds) Persuasion: psychological insights and perspectives. Sage Publications, Thousand Oaks, pp. 143-169

Cox KS (2010) Elevation predicts domain-specific volunteerism 3 months later. J Posit Psychol 5(5):333-341. https://doi.org/10.1080/17439760.2010.507468

Fredman LA, Bastian B, Swann WB (2017) God or country? Fusion with Judaism predicts desire for retaliation following Palestinian stabbing Intifada. Soc Psychol Personal Sci 8(8):882-887. https://doi.org/10.1177/1948550617693059

Gómez Á, Brooks ML, Buhrmester MD, Vázquez A, Jetten J, Swann WB (2011a) On the nature of identity fusion: insights into the construct and a new measure. J Pers Soc Psychol 100(5):918-933. https://doi.org/10.1037/ a 0022642

Gómez Â, Chinchilla J, Vázquez A, López-Rodríguez L, Paredes B, Martínez M (2020) Recent advances, misconceptions, untested assumptions, and future research agenda for identity fusion theory. Soc Pers Psychol Compass. https:// doi.org/10.1111/spc3.12531

Gómez Á, López-Rodríguez L, Sheikh $\mathrm{H}$ et al. (2017) The devoted actor's will to fight and the spiritual dimension of human conflict. Nat Hum Behav 1 (9):673-679. https://doi.org/10.1038/s41562-017-0193-3

Gómez Á, Morales JF, Hart S, Vázquez A, Swann WB (2011b) Rejected and excluded forevermore, but even more devoted. Pers Soc Psychol Bull 37 (12):1574-1586. https://doi.org/10.1177/0146167211424580

Gómez Á, Vázquez A, López-Rodríguez L, Talaifar S, Martínez M, Buhrmester MD, Swann Jr WB (2019) Why people abandon groups: degrading relational vs collective ties uniquely impacts identity fusion and identification. J Exp Soc Psychol 1(85):103853. https://doi.org/10.1016/j-jesp.2019.103853

Haidt J (2003) The positive emotion of elevation. Prev Treat 3(1). https://doi.org/ $10.1037 / 1522-3736.3 .1 .33 \mathrm{c}$

Hayes AF (2018) Introduction to mediation, moderation, and conditional process analysis: a regression-based approach. The Guilford Press, New York

Henrich J, Gil-White FJ (2001) The evolution of prestige: freely conferred deference as a mechanism for enhancing the benefits of cultural transmission. Evol Hum Behav 22(3):165-196. https://doi.org/10.1016/s1090-5138(00)00071-4

Immordino-Yang MH, Mccoll A, Damasio H, Damasio A (2009) Neural correlates of admiration and compassion. Proc Natl Acad Sci USA 106(19):8021-802. https://doi.org/10.1073/pnas.0810363106

Jong J, Whitehouse H, Kavanagh C, Lane J (2015) Shared negative experiences lead to identity fusion via personal reflection. PLoS ONE 10(12). https://doi.org/ 10.1371/journal.pone.0145611

Jiménez J, Gómez Á, Buhrmester MD, Vázquez A, Whitehouse H, Swann WB (2015) The dynamic identity fusion index. Soc Sci Comput Rev 34 (2):215-228. https://doi.org/10.1177/0894439314566178

Kapitány R, Kavanagh CM, Buhrmester M, Newson M, Whitehouse H (2018) Ritual, identity fusion, and the inauguration of President Trump: a pseudoexperiment of Ritual Modes theory. https://doi.org/10.31234/osf.io/53waf

Kavanagh CM, Jong J, Mckay R, Whitehouse H (2018) Positive experiences of high arousal martial arts rituals are linked to identity fusion and costly pro-group actions. Eur J Soc Psychol 49(3):461-481. https://doi.org/10.1002/ejsp.2514

Keltner D, Haidt J (2003) Approaching awe, a moral, spiritual, and aesthetic emotion. Cogn Emot 17(2):297-314. https://doi.org/10.1080/02699930302297

Kruglanski AW, Bélanger JJ, Gunaratna R (2019) The three pillars of radicalization. https://doi.org/10.1093/oso/9780190851125.001.0001

Kruglanski AW, Gelfand MJ, Bélanger JJ, Gunaratna R, Hettiararchchi M (2014) Deradicalizing the Liberation Tigers of Tamil Eelam (LTTE): some preliminary findings. In: Silke A (Ed.) Prisons, terrorism and extremism: critical issues in management, radicalization and reform. Routledge, London

Kruglanski AW, Webber D, Koehler D (2019) The radicals journey. https://doi.org/ 10.1093/oso/9780190851095.001.0001

Kunst JR, Boos B, Kimel SY, Obaidi M, Shani M, Thomsen L (2018) Engaging in extreme activism in support of others' political struggles: the role of politically motivated fusion with out-groups. PLos ONE 13(1). https://doi.org/10.1371/ journal.pone.0190639

Lobato RM, Sainz M (2019) On the way to fusion through the pilgrims' route: factors that maintain identity fusion in collective rituals. Group Process Intergroup Relat. https://doi.org/10.1177/1368430219849690

Misch A, Fergusson G, Dunham Y (2018) Temporal dynamics of Partisan identity fusion and prosociality during the 2016 U.S. Presidential Election. https://doi. org/10.31234/osf.io/bhxwp 
Newson M, Buhrmester M, Whitehouse H (2016) Explaining lifelong loyalty: the role of identity fusion and self-shaping group events. PLoS ONE 11(8). https://doi.org/10.1371/journal.pone.0160427

North AC, Tarrant M, Hargreaves DJ (2004) Effects of music on helping behavior: a field study. Environ Behav 36:266-275. https://doi.org/10.1177/ 0013916503256263

Nyamutata C (2020) Young terrorists or child soldiers? ISIS children, International Law and Victimhood. J Confl Secur Law https://doi.org/10.1093/jcsl/krz034

Onu D, Kessler T, Smith JR (2016) Admiration: a conceptual review. Emotion Rev 8(3):218-230. https://doi.org/10.1177/1754073915610438

Páez D, Rimé B, Basabe N, Wlodarczyk A, Zumeta L (2015) Psychosocial effects of perceived emotional synchrony in collective gatherings. J Pers Soc Psychol 108(5):711-729. https://doi.org/10.1037/pspi0000014

Penner LA, Dovidio JF, Piliavin JA, Schroeder DA (2005) Prosocial behavior: multilevel perspectives. Annu Rev Psychol 56(1):365-392. https://doi.org/ 10.1146/annurev.psych.56.091103.070141

Pohling R, Diessner R (2016) Moral elevation and moral beauty: a review of the empirical literature. Rev Gen Psychol 20(4):412-425. https://doi.org/10.1037/ gpr0000089

Saleem M, Anderson CA, Barlett CP (2015) Assessing helping and hurting behaviors through the tangram help/hurt task. Pers Soc Psychol Bull 41 (10):1345-1362. https://doi.org/10.1177/0146167215594348

Salovey R, Mayer JD, Rosenhan DL (1991) Mood and helping: mood as motivator of helping and helping as regulator of mood. In: Clark M (ed) Review of personality and social psychology. Prosocial behavior, vol 12. Sage, Newbury Park, pp. 215-237

Schindler I, Zink V, Windrich J, Menninghaus W (2013) Admiration and adoration: their different ways of showing and shaping who we are. Cognition Emotion 27(1):85-118. https://doi.org/10.1080/02699931.2012.698253

Schnall S, Roper J, Fessler DM (2010) Elevation leads to altruistic behavior. Psychol Sci 21(3):315-320. https://doi.org/10.1177/0956797609359882

Segal K, Jong J, Halberstadt J (2018) The fusing power of natural disasters: an experimental study. Self Identity 17(5):574-586. https://doi.org/10.1080/ 15298868.2018.1458645

Sheikh H, Gómez Á, Atran S (2016) Empirical evidence for the devoted actor model. Curr Anthropol 57(S13). https://doi.org/10.1086/686221

Smith RH (2000) Assimilative and contrastive emotional reactions to upward and downward social comparisons Handb Soc Comp 2000:173-200. https://doi. org/10.1007/978-1-46154237-7_10

Stellar JE, Gordon AM, Piff PK et al. (2017) Self-transcendent emotions and their social functions: compassion, gratitude, and awe bind us to others through prosociality. Emot Rev 9(3):200-207. https://doi.org/10.1177/1754073916684557

Sweetman J, Spears R, Livingstone AG, Manstead AS (2013) Admiration regulates social hierarchy: antecedents, dispositions, and effects on intergroup behavior. J Exp Soc Psychol 49(3):534-542. https://doi.org/10.1016/j.jesp.2012.10.007

Swann WB, Buhrmester MD, Gómez A et al. (2014) What makes a group worth dying for? Identity fusion fosters perception of familial ties, promoting selfsacrifice. J Pers Soc Psychol 106(6):912-926. https://doi.org/10.1037/a0036089

Swann WB, Gómez Á, Buhrmester MD, López-Rodríguez L, Jiménez J, Vázquez A (2014) Contemplating the ultimate sacrifice: identity fusion channels progroup affect, cognition, and moral decision making. J Pers Soc Psychol 106 (5):713-727. https://doi.org/10.1037/a0035809

Swann WB, Gómez Á, Huici C, Morales JF, Hixon JG (2010) Identity fusion and self-sacrifice: arousal as a catalyst of pro-group fighting, dying, and helping behavior. J Pers Soc Psychol 99(5):824-841. https://doi.org/10.1037/a0020014

Swann WB, Gómez Á, Seyle DC, Morales JF, Huici C (2009) Identity fusion: the interplay of personal and social identities in extreme group behavior. J Pers Soc Psychol 96(5):995-1011. https://doi.org/10.1037/a0013668

Swann WB, Gómez Á, Vázquez A, Guillamón A, Segovia S, Carillo B (2015) Fusion with the cross-gender group predicts genital sex reassignment surgery. Arch Sex Behav 44(5):1313-1318. https://doi.org/10.1007/s10508-014-0470-4

Swann WB, Jetten J, Gómez Á, Whitehouse H, Bastian B (2012) When group membership gets personal: a theory of identity fusion. Psychol Rev 119 (3):441-456. https://doi.org/10.1037/a0028589

Time (2019) Greta Thunberg: TIME's person of the year 2019. https://time.com/ person-of-the-year-2019-greta-

thunberg/?utm_source $=$ twitter\&utm_medium $=$ social\&utm_campaign $=$ perrson-of-the-year\&utm_term=_\&linkId=78763203. Accessed 14 May 2020

Tornero E, Sánchez-Romera JF, Morosoli JJ, Vázquez A, Gómez Á, Ordoñana JR (2017) Altruistic behavior among twins. Hum Nat 29(1):1-12. https://doi. org/10.1007/s12110-017-9304-0
UN Security Council Committee (2019) Letter dated 15 July 2019 from the Chair of the Security Council Committee Established pursuant to Resolutions 1267 (1999), 1989 (2011) and 2253 (2015) concerning Islamic State in Iraq and the Levant (Da'esh), Al-Qaida and Associated Individuals, Groups, Undertakings and Entities addressed to the President of the Security Council. United Nations Digital Library. http://digitallibrary.un.org/ record/3813209? $\ln =$ en\#record-files-collapse-header. Accessed May 28 2020

Vázquez A, Gómez Á, Ordoñana JR, Swann WB, Whitehouse H (2017) Sharing genes fosters identity fusion and altruism. Self Identity 16(6):684-702. https:// doi.org/10.1080/15298868.2017.1296887

Vázquez A, López-Rodríguez L, Martínez M, Atran S, Gómez Á (2020) Threat enhances aggressive inclinations among devoted actors via increase in their relative physical formidability. Pers Soc Psychol Bull https://doi.org/10.1177/ 0146167220907466

Vianello M, Galliani EM, Haidt J (2010) Elevation at work: the effects of leaders' moral excellence. J Posit Psychol 5(5):390-411. https://doi.org/10.1080/ 17439760.2010 .516764

Vyver JVD, Abrams D (2015) Testing the prosocial effectiveness of the prototypical moral emotions: elevation increases benevolent behaviors and outrage increases justice behaviors. J Exp Soc Psychol 58:23-33. https://doi.org/ 10.1016/j.jesp.2014.12.005

Webber D, Chernikova M, Kruglanski AW, Gelfand MJ, Hettiarachchi M, Gunaratna R, Belanger JJ (2018) Deradicalizing detained terrorists. Pol Psychol 39(3):539-556. https://doi.org/10.1111/pops.12428

Whitehouse H, Jong J, Buhrmester MD et al (2017) The evolution of extreme cooperation via shared dysphoric experiences. Sci Rep 7(1). https://doi.org/ $10.1038 /$ srep 44292

Whitehouse H, Mcquinn B, Buhrmester M, Swann WB (2014) Brothers in arms: Libyan revolutionaries bond like family. Proc Natl Acad Sci USA 111 (50):17783-17785. https://doi.org/10.1073/pnas.1416284111

Zumeta L, Basabe N, Wlodarczyk A, Bobowik M, Paez D (2016) Flujo Compartido y Reuniones Colectivas Positivas. An Psicol 32(3):717. https://doi.org/ 10.6018/analesps.32.3.261651

\section{Funding}

Support for this research was provided by Ministerio de Ciencia, Innovación y Universidades from the Spanish Government, Grant/Award Number: RTI2018-093550-B100, and by the grant AFOSR FA9550-17-C-0023 P00003.

\section{Competing interests}

The authors declare no competing interests.

\section{Additional information}

Supplementary information The online version contains supplementary material available at https://doi.org/10.1057/s41599-021-00734-9.

Correspondence and requests for materials should be addressed to J.J.B.

Reprints and permission information is available at http://www.nature.com/reprints

Publisher's note Springer Nature remains neutral with regard to jurisdictional claims in published maps and institutional affiliations.

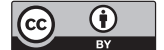

Open Access This article is licensed under a Creative Commons Attribution 4.0 International License, which permits use, sharing, adaptation, distribution and reproduction in any medium or format, as long as you give appropriate credit to the original author(s) and the source, provide a link to the Creative Commons license, and indicate if changes were made. The images or other third party material in this article are included in the article's Creative Commons license, unless indicated otherwise in a credit line to the material. If material is not included in the article's Creative Commons license and your intended use is not permitted by statutory regulation or exceeds the permitted use, you will need to obtain permission directly from the copyright holder. To view a copy of this license, visit http://creativecommons.org/ licenses/by/4.0/.

(C) The Author(s) 2021 